\title{
Новый гетерозисный гибрид томата
}

\section{P.X. Беков, С.В. Максимов}

Представлен исходный материал для создания нового гибрида томата $F_{1}$ Заур с коричневой окраской плодов, с высокими вкусовыми качествами и лежкостью. Гетерозисный гибрид предназначен для выращивания в пленочных теплицах фермерских и приусадебных хозяйств России. Дана его характеристика, в том числе в сравнении со стандартом, гибридом $\mathrm{F}_{1}$ Интуиция.

Ключевые слова: томат, гибрид $\mathrm{F}_{1}$, плод, окраска, лежкость.

$\mathrm{H}$ аучно-исследовательские учреждения в России и за рубежом ведут постоянную работу по созданию сортов и гибридов томата, обладающих высокими качествами зрелых плодов. Однако на рынке по-прежнему мало сортов и гибридов с хорошими вкусовыми качествами (за исключением гибридов томата типа черри) [1, 2, 3].

Вместе с тем селекционно-семеноводческие компании иногда рекламируют сорта с темно-коричневой окраской зрелых плодов, непригодные для выращивания в пленочных теплицах. Такие сорта имеют тенденцию к осыпанию завязи и плодов при подвязке к шпалере в процессе ухода за растением, т.к. плодоножка имеет сочленение (ген ј+) [4, 5].

Учитывая необходимость создания новых сортов и гибридов томата с высоким качеством плодов для пленочных теплиц, начиная с 2010 года во ВНИИ овощеводства (ФГБНУ ФНЦО) совместно с компанией «Поиск» проводят исследования по селекции новых $F_{1}$ гибридов с коричневой окраской плодов и высокими вкусовыми качествами.

Исходным материалом при создании новых $F_{1}$ гибридов служили мутантные геноносители маркерных признаков, созданные ранее в отделе селекции и семеноводства ВНИИ овощеводства [2-7], а именно:

- sp+ (self-pruning) - индетерминантный габитус растения;

- j-2 (jointless) - плодоножка без сочленения;

- S (self-incompatibility) - простое цветочное соцветие;

- Gr (green ripe) - темно-коричневая окраска плода.

В результате совместно проведенной селекционной работы был создан ряд перспективных мутантных линий, которые мы используем при гетерозисной селекции. Кроме того, в 2017 году создан и включен в Госреестр среднеспелый гибрид $F_{1}$ Клад овощевода. Это гибрид томата салатного типа с высоким качеством зрелых плодов. Семена гибрида можно приобрести по адресу: 141015, Московская обл., Раменский

Хозяйственные и биологические свойства нового гибрида томата $F_{1}$ Заур в сравнении со стандартным гибридом $F_{1}$ Интуиция (2014-2016 годы)

\begin{tabular}{|l|c|c|}
\hline \multicolumn{1}{|c|}{ Показатель } & $\mathrm{F}_{1}$ Заур & $\begin{array}{c}\mathrm{F}_{1} \text { Интуиция } \\
\text { (стандарт) }\end{array}$ \\
\hline $\begin{array}{l}\text { Число суток от полных всходов до начала созревания } \\
\text { плодов (10-15\% зрелых плодов гибрида) }\end{array}$ & $105-115$ & $110-115$ \\
\hline $\begin{array}{l}\text { Период плодоношения, суток } \\
\text { (начало - конец плодоношения) }\end{array}$ & $45-50$ & $42-47$ \\
\hline Общая урожайность, кг/м² & $15,5-17,7$ & $16,7-18,9$ \\
\hline Средняя масса товарного плода, г & $45-55$ & $112-120$ \\
\hline Треснувших плодов от общего урожая, \% & $0,9-1,0$ & $2,0-2,5$ \\
\hline Больных плодов, \% & $1,0-1,2$ & $1,3-1,6$ \\
\hline $\begin{array}{l}\text { Дегустационная оценка свежих плодов } \\
\text { (по пятибалльной шкале) }\end{array}$ & $4,5-5,0$ & $4,2-4,3$ \\
\hline Содержание в плодах сухого вещества, \% & $7,3-7,6$ & $6,2-6,5$ \\
\hline
\end{tabular}

район, дер. Верея, Островецкое ш., строение 500-501; www.semenasad. ru.

Сегодня нами создан новый гибрид томата $F_{1}$ Заур с высокими вкусовыми качествами и лежкостью плодов, предназначенный для выращивания в пленочных теплицах фермерских и приусадебных хозяйств России.

Краткая характеристика нового гибрида

Гибрид томата $\mathrm{F}_{1}$ [а-45 (311×292)] Заур. Среднеспелый, вегетационный период от всходов до начала созревания плодов 107-112 суток. Растение индетерминантное, высота главного стебля 185-195 см. Листья обыкновенные, светло-зеленые, среднего размера. Соцветие простое или промежуточного типа. Первое соцветие закладывается над 8-9 листом, последующие соцветия - через три листа. Плодов в соцветии 7-9. Они сливовидной или эллиптической формы (индекс 1,401,55), массой 45-55 г, камер в плоде 2-3, расположение их правильное. Плоды высокой плотности, устойчивые к растрескиванию и осыпанию, т.к. плодоножка без сочленения (ген j-2). Незрелый плод темно-зеленой

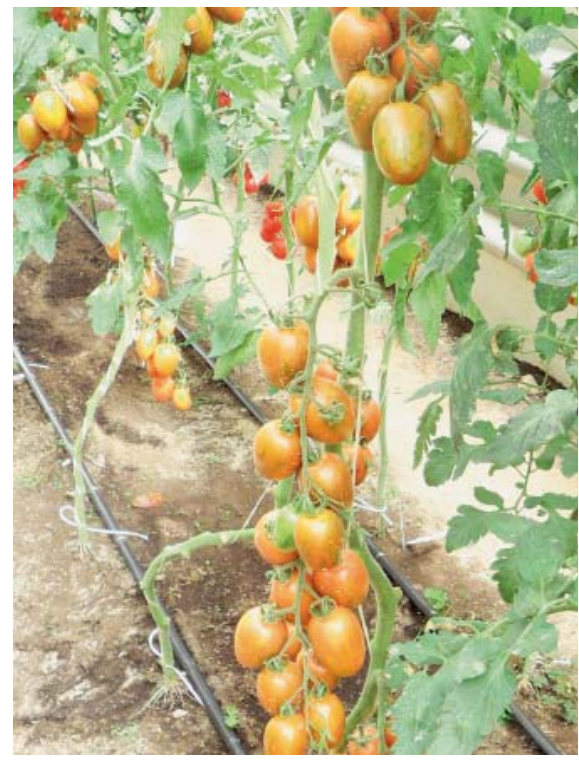

Плоды гибрида $F_{1}$ Заур в соцветии

№7/2019 Картофель и овощи 


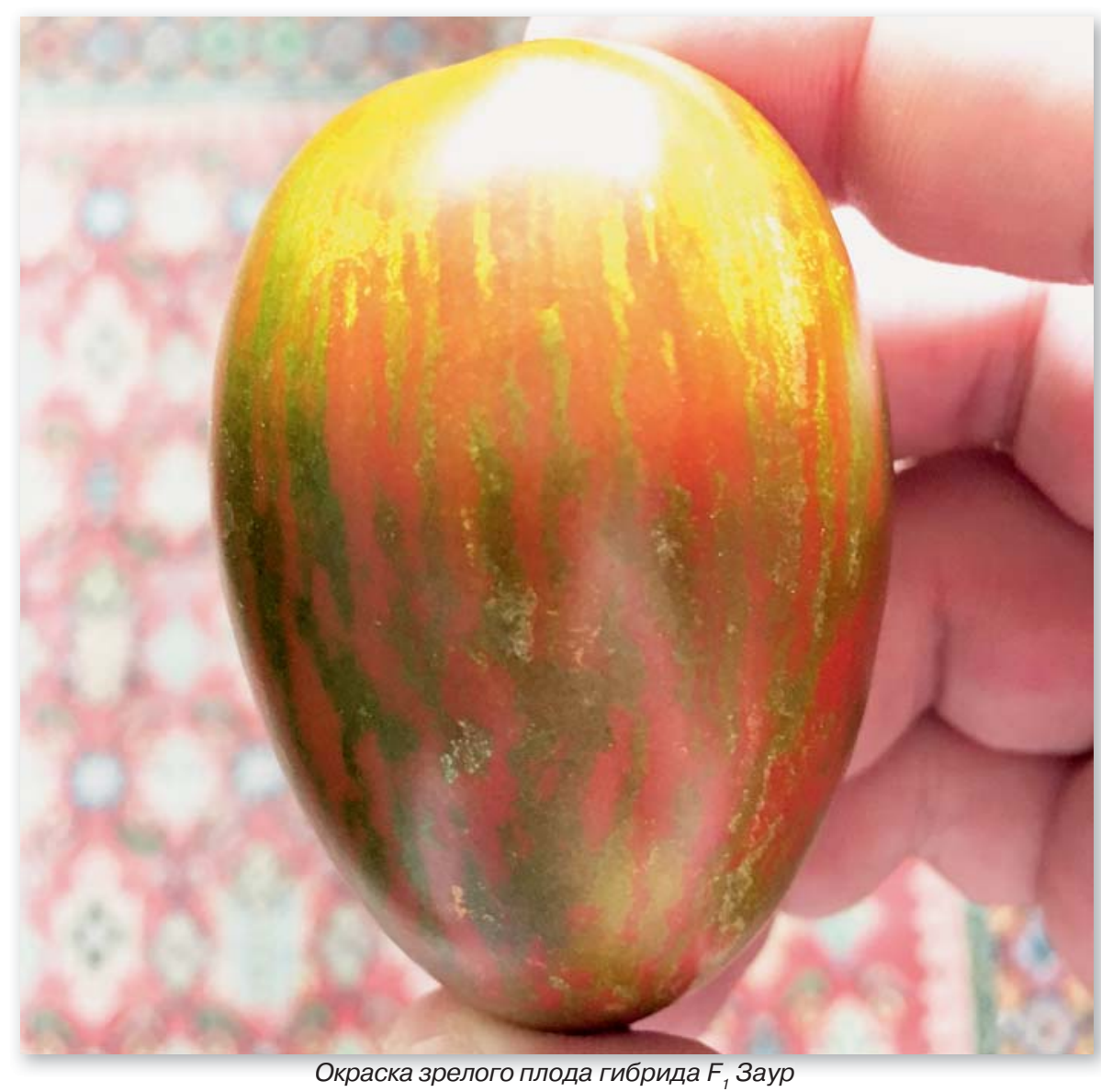

$\frac{\text { Об авторах }}{\text { Беков Рустам Хизриевич, док- }}$ тор с. - х. наук, гл.н.с. отдела селекции и семеноводства, Всероссийский научно-исследовательский иститут овощеводства - филиал ФГБНУ «Федеральный научный центр овощеводства». E-mail: vniioh@yandex.ru Максимов Сергей Васильевич, канд. с. - х. наук, генеральный директор, ООО «Центр-Огородник». E-mail: info@semenasad.ru. Интернет-сайт: www.semenasad.ru

\section{New heterotic tomato hybrid} R.Kh. Bekov, DSc., chief research fellow of department of breeding and seed growing, All-Russian Research Institute of Vegetable Growing - the branch FSBSI «Federal Scientific Vegetable Center» E-mail:vniioh@yandex.ru S.V. Maksimov, $P h D$, director general of Centr-Ogorodnik Ltd

E-mail: info@semenasad.ru. Website: www.semenasad.ru

Summary. The initial material for breeding of a new hybrid of tomato $F_{1}$ Zaur with brown colour of fruits, with high taste and keeping quality is presented. The heterotic hybrid is intended for growing in plastic greenhouses of farms and household farms of Russia. Its characteristic is given, including in comparison with the standard, hybrid $F_{1}$ Intuition. Keywords: tomato, hybrid $F_{1}$, fruit, colour, keeping quality.

окраски, при созревании - коричневый. Плоды очень хорошего качества и вкуса, содержат сухого вещества 7,3-7,6\%. Урожайность гибрида $15,5-17,7$ кг/м², что на уровне стандарта - гибрида $\mathrm{F}_{1}$ Интуиция.

\section{Библиографический список}

1.Беков Р.Х., Тарасенков И.И. Использование сигнальных признаков томата (семян, плода и плодоножки) для повышения эффективности селекционного процесса. Тезисы докладов научно-теоретической конференции, посвященной 100 -летию со дня рождения Б.В. Квасникова. М., 1998. C. $85-86$.

2.Беков Р.Х., Тарасенков И.И. Перспективные сортообразцы томата с сигнальными признаками // Картофель и овощи. 1999. № 6. С. 27.

3.Беков Р.Х., Костенко А.Н. Изучение и отбор исходного материала томата с сигнальными признаками для использования его в гетерозисной селекции для защищенного грунта // Овощеводство: Проблемы. Перспективы. В сб. науч. трудов ВНИИО. Т. 2. М., 2002. C. 27-33.

4.Беков Р.Х., Костенко А.Н., Тарасенков И.И. Использование маркерного мутанта семян (bs - brown seed) при гетерозисной селекции томата для защищенного грунта // Селекция, семеноводство и биотехнология овощных и бахчевых культур. В сб. науч. тр. ВниИО. М., 2003. С. 58-62.

5.Беков Р.Х., Костенко А.Н. Использование маркерных мутантов семян томата (гены bs, bs-2) для создания гетерозисных гибридов // Тезись международной научно-практической конференции по пасленовым культурам. Астрахань, 2003. C. 58 .

\section{К столетию со дня основания Всероссийского научно-исследовательского института картофельного хозяйства имени А.Г. Лорха}

Уважаемые коллеги - картофелеводы России!

В 2020 году Всероссийский научно-исследовательский институт картофельного хозяйства имени А.Г. Лорха (ФГБНУ ВНИИКХ) будет отмечать столетие со дня основания. В рамках проведения юбилейных мероприятий планируется установить памятник картофелю - особой культуре, историческая роль которой в жизни человека высоко оценивается во всем мире. Сегодня ведется сбор средств на установку монумента, проект которого одобрен Администрацией Люберецкого района Московской области.

От имени оргкомитета по проведению юбилейных мероприятий ФГБНУ ВНИИКХ обращаемся к картофелеводам России с просьбой оказать возможную финансовую помощь на установку монумента. Оплату физическими лицами можно провести через банкомат по опции «Оплата юридическими лицами».

Добровольный взнос можно перечислить на расчетный счет:

ООО «Тест-картофель». Юридический адрес:140051, Московская обл., Люберецкий р-н, п. Красково, ул. Лорха, 8.

Фактический адрес: 140051, Московская обл., Люберецкий р-н, п. Красково, ул. Лорха, 23.

ИНН 5027200775 КПП 502701001

БАНК «Возрождение»

(ПАО) г. Москва г. Люберцы

р/с. 40702810902600143041 к/с. 30101810900000000181 БИк044525181

Примите нашу глубокую признательность и благодарность за вашу поддержку.

Оргкомитет по проведению юбилейных мероприятий ФГБНУ ВНИИКХ 